(C) Group of authors, 2021

UDC 616.34-008.8+616.36:616-092

DOI - https://doi.org/10.14300/mnnc.2021.16052

ISSN - 2073-8137

\title{
METABOLIC INTEGRATION OF THE «GUT - LIVER॥: THEORETICAL BASIS OF INTERACTION AND THERAPEUTIC PROSPECTS
}

\author{
Shevandova A. A. ${ }^{1}$, Fomochkina I. I. ${ }^{1}$, Kubyshkin A. V. ${ }^{1}$, Sorokina L. E. ', \\ Gordienko A. I. ' , Gorbunov A. A. ' , Makalish T. P. ' , Yurchenko K. A. ${ }^{2}$ \\ ${ }^{1}$ Medical Academy named after S. I. Georgievsky of V. I. Vernadsky Crimean \\ Federal University, Simferopol, Russian Federation \\ 2 Tauride Academy of V. I. Vernadsky Crimean Federal University, Simferopol, \\ Russian Federation
}

\section{МЕТАБОАИЧЕСКАЯ ИНТЕГРАЦИЯ ॥КИШЕЧНИК - ПЕЧЕНЬ॥: ТЕОРЕТИЧЕСКИЕ ОСНОВЫ ВЗАИМОАЕЙСТВИЯ И ТЕРАПЕВТИЧЕСКИЕ ПЕРСПЕКТИВЫ}

\author{
А. А. Шеванаова ${ }^{1}$, И. И. Фомочкина ${ }^{1}$, А. В. Кубышкин ${ }^{1}$, А. Е. Сорокина ${ }^{1}$, \\ А. И. Гораиенко ', А. А. Горбунов ', Т. П. МакаАиш ', К. А. Юрченко ${ }^{2}$
${ }^{1}$ МеАицинская акалемия им. С. И. Георгиевского Крымского фелерального университета им. В. И. ВернаАского, Симферополь, Российская ФеАерация 2 Таврическая акалемия Крымского фелерального университета им. В. И. Верналского, Симферополь, Российская ФеАерация

Recently, the role of intestinal microbiota in maintaining metabolic and immunological homeostasis has received increasing attention. Many studies have reported a close association between intestinal ecosystem dysbiosis and the development of several pathological processes, including autoimmune, metabolic, and malignant diseases. Because there is a steady increase in the numbers of patients with liver diseases, future studies of the function of the gut-liver axis will be important. The relationship between the liver and intestines occurs through bidirectional signal exchange via metabolic, epigenetic, and neuroendocrine mechanisms. The quantitative and qualitative characteristics of the intestinal microflora can affect intestinal permeability and the translocation of endotoxins, as well as control the activity of Kupffer cells and the transcriptional activation of many proinflammatory genes and cytokines in the liver through the production of various metabolites. The normalization of intestinal microflora might be a promising method for the treatment and prevention of socially significant liver diseases.

Keywords: intestinal microbiota, intestinal microflora, gut-liver metabolic axis, non-alcoholic fatty liver disease, cirrhosis, hepatocellular carcinoma

В последние годы все более пристальное внимание ученых и клиницистов привлекает вопрос о роли кишечной микробиоты в поддержании метаболического и иммунологического гомеостаза организма. В современной научной литературе имеется достаточно много сведений о тесной ассоциации дисбиоза кишечника с развитием ряда патологических процессов, включая аутоиммунные, метаболические и злокачественные заболевания. В связи с неуклонным ростом числа пациентов с тяжелыми заболеваниями печени перспективным становится изучение особенностей функционирования оси «кишечник-печень». Наличие перекрестных взаимоотношений между печенью и кишечником обеспечивается двунаправленным обменом различными сигналами посредством метаболических, эпигенетических и нейроэндокринных механизмов. Качественный состав и количественные характеристики кишечной микрофлоры способны оказывать существенное влияние не только на проницаемость кишечного барьера и бактериальную транслокацию, но также контролировать активность клеток Купфера и уровень транскрипции большого числа генов, участвующих в воспалительном ответе на бактериальные стимулы. Восстановление кишечной микробиоты может рассматриваться в качестве перспективного подхода к лечению и профилактике социально значимых заболеваний печени.

Ключевые слова: микробиота кишечника, метаболическая ось «кишечник-печень», неалкогольная жировая болезнь печени, цирроз печени, гепатоцеллюлярная карцинома

For citation: Shevandova A. A., Fomochkina I. I., Kubyshkin A. V., Sorokina L. E., Gordienko A. I., Gorbunov A. A., Makalish T. P., Yurchenko K. A. METABOLIC INTEGRATION OF THE «GUT - LIVER»: THEORETICAL BASIS OF INTERACTION AND THERAPEUTIC PROSPECTS. Medical News of North Caucasus. 2021;16(2):222-226.

DOI - https://doi.org/10.14300/mnnc.2021.16052 
Для цитирования: Шевандова А. А., Фомочкина И. И., Кубышкин А. В., Сорокина Л. Е., Гордиенко А. И., Горбунов А. А., Макалиш Т. П., Юрченко К. А. МЕТАБОЛИЧЕСКАЯ ИНТЕГРАЦИЯ «КИШЕЧНИК - ПЕЧЕНЬ»: ТЕОРЕТИЧЕСКИЕ ОСНОВЫ ВЗАИМОДЕЙСТВИЯ И ТЕРАПЕВТИЧЕСКИЕ ПЕРСПЕКТИВЫ. МедИцинскиЙ вестник СеверноГО Кавказа. 2021;16(2):222-226. DOI - https://doi.org/10.14300/mnnc.2021.16052

\author{
BA - bile acids \\ FXR - farnesoid X-receptors \\ $N F-\kappa B$ - nuclear factor $-\kappa B$ \\ NKT - natural killer T cells
}

TGR5 - G-protein-coupled receptor
TLR - Toll-like receptor
TNF- $\alpha$ - tumor necrosis factor alpha
L aunched in 2007, the global large-scale Human Microbiome Project, which followed the Human Genome program, made several discoveries that radically changed the existing ideas about the role of microorganisms in our lives [1]. The genetic analyses of biomaterial samples demonstrated the human intestine contains 500 to 1000 species of microorganisms with total biomass of 1-3\% of total body weight [2]. Furthermore, the human genome contains approximately 22,000 genes that encode proteins and the microbiome contains approximately 8 million unique bacterial genes [3].

Most microorganisms that form the microbiota of the gastrointestinal tract are bacterial cells, of which more than $90 \%$ belong to two taxa - Firmicutes and Bacteroidetes. Of note, the ratio between Firmicutes and Bacteroidetes is considered the most important indicator of the functional state of the intestinal microbiota. Normally, the composition of the intestinal microflora is dominated by obligate anaerobes, whereas facultative anaerobes are present at lower amounts, mainly in the proximal parts of the small intestine. Furthermore, the distal parts of the intestine contain significantly greater numbers of microorganisms compared with the proximal parts of the small intestine $[4,5]$. According to the type of interaction with the gastrointestinal tract, all microorganisms that colonize the intestine are usually divided into cavity (lumen) and parietal (mucosa) microflora [6, 7]. The intestinal microflora include obligate and transient microorganisms and in general, the intestinal microbiome can be considered a labile and potentially-modifiable population of various microorganisms that coexist within the gastrointestinal tract. The targeted correction of the species composition of the intestinal microflora and their interspecific relationships might provide an innovative approach for the prevention and treatment of many socially significant diseases, especially all-liver pathology.

According to modern concepts, the gut microbiota is functionally considered an independent «organ» that has a key role in food digestion as well as maintaining the immunological and metabolic homeostasis of the macroorganism $[8,9]$. Considering the large contribution of the intestinal microbiota to the regulation of the metabolism of organic substances and trace elements, the creation of colonization resistance, maintenance of the integrity of the intestinal barrier, provision of immunological tolerance, it follows that dysbiotic disorders are closely associated with a cascade of systemic pathological reactions underlying the development of a wide range of diseases [10-12].

Given the discouraging global trend in the field of clinical medicine with regard to the increase in the number of patients with liver diseases, the study of the function of metabolic «intestine-liver axis», has become particularly important $[13,14]$. There is a close interaction between the liver and the intestine, related to their anatomical and physiological features. Products synthesized by the liver enter the intestinal lumen and are involved in the assimilation of various nutrients. Furthermore, $70 \%$ of the blood passing through the portal vein system to the liver is pro- vided by the venous outflow from the intestine $[15,16]$. Therefore, a violation of the intestinal barrier allows the entry of various toxicants that can affect the liver. In turn, liver dysfunction can cause severe intestinal disorders. Indeed concomitant dysbiotic changes in the intestinal microbiota are observed in $25-75 \%$ of patients suffering from chronic liver diseases, which are commonly related to excessive bacterial growth [17].

Recent studies of patients with verified liver diseases reported that qualitative changes occur in the intestinal microflora characterized by an increase in the number of aerobic and "proinflammatory» microorganisms (Enterobacteriaceae, Enterococcus, and Clostridium), as well as a significant decrease in the number of «antiinflammatory" microorganisms (Lactobacillus and Bifidobacterium) [18, 19]. Furthermore, Michail et al. (2015) reported a study of children and adolescents with non-alcoholic fatty liver disease where representatives of the genera Gammaproteobacteria and Prevotella predominated in the intestinal microbiome [20]. In overweight adults or those with non-alcoholic fatty liver disease, high numbers of microorganisms from the genera Pasteurellaceae, Lactobacillaceae, Veillonellaceae, as well as some genera of Lachnospiraceae (Dorea, Robinsoniella, and Roseburia) were found in the intestinal microflora [21]. A metagenomic study of fecal samples from patients with cirrhosis of the liver with hepatocellular carcinoma reported that the amount of Escherichia coli was significantly higher compared with patients without liver pathology [22]. Furthermore, patients with primary liver cancer had a high proportion of representatives of the genera Pasteurellaceae, Veillonellaceae, and some genera of Lachnospiraceae in the intestinal microbiome [23]. Currently, which qualitative changes occur in the composition of the intestinal microbiota in patients with liver diseases remain unclear and require further study.

Regarding the molecular and biochemical aspects of the function of the metabolic «intestinal-hepatic axis», the relationship between the liver and the intestine is provided by the bidirectional exchange of various signals through metabolic, epigenetic, and neuroendocrine mechanisms $[24,25]$. The qualitative composition of the intestinal microflora and its quantitative characteristics can have a significant impact on intestinal barrier permeability and bacterial translocation, as well as controlling the activity of Kupffer cells and the level of transcription of many genes involved in the inflammatory response to bacterial stimuli $[26,27]$.

Although most products of the intestinal microbiota can have a regulatory effect on the liver under normal and pathological conditions, interactions between the intestinal-liver communication system often occur via intestinal lipopolysaccharide, an obligate structural and functional component of the cell wall of all $\mathrm{Gr}^{-}$bacteria, the level of which was increased significantly in the portal and systemic blood flow in various liver diseases [28]. Toll-like receptor (TLR) 4, the main signaling cell receptor for lipopolysaccharide, is expressed on the plasma membrane of Kupffer cells. The interaction of lipopolysaccha- 
ride with TLR4 activates inflammatory signaling pathways (NF-kB pathway, MAP-kinase pathway, AP-1) and nuclear transcription factors to promote the intensive production of proinflammatory cytokines (TNF- $\alpha, \mathrm{IL}-1, \mathrm{IL}-6)$. In addition, it blocks the transmission of insulin signals and contributes to the emergence of insulin resistance [29, 30]. Under the conditions of inflammation and oxidative stress, the increased production of inflammatory mediators causes chronic damage and the compensatory proliferation of hepatocytes. In addition, the state of insulin resistance initiates the release of free fatty acids from adipocytes, the accumulation of which contributes to liver steatosis [31] Ultimately, these pathogenetic pathways can lead to cellular dysplasia and the development of carcinogenesis in the hepatic parenchyma. Park et al. (2010) provided data indicating the development of hepatocellular carcinoma under obese conditions as a direct consequence of TNF- $\alpha$ and IL-6 hyperproduction [32]. Another study provided evidence that proinflammatory cytokines in the liver triggered the oncogenic transcription factor STAT3, which enhanced proliferative and dysplastic changes in liver cells [33].

Another important element in the "gut-liver» communication axis is bile acids (BA), which are cholesterol metabolites. BA that function as signaling molecules to control metabolic homeostasis are a promising target for the development of innovative targeted drugs [34]. In the liver, primaryBA (in particular, cholic and chenodeoxycholic acids) are actively conjugated with amino acids (glycine, taurine) and released by hepatocytes into the bile. In the small intestine, about $95 \%$ of BA are reabsorbed, and the rest is metabolized by the intestinal microbiota to secondary BA (in particular, deoxycholic and lithocholic acids) [35].

In disorders of the composition of normal intestinal microflora, bacterial cells use dietary choline for the synthesis of trimethylamine, which is rapidly metabolized by liver flavin monooxygenases to trimethylamine oxide that increases the permeability of the intestinal barrier and varies lipid metabolism (in particular, by reducing the formation of phosphatidylcholine, reducing the acceptor properties of high-density lipoproteins and increasing the secretion of very low-density lipoproteins) [36, 37].

Previously, BA were considered to only have surface-active properties, but after the discovery of farnesoid X-receptors (FXR) at the end of the last century, their range of functions was significantly expanded. In particular, primary and secondary BA interact with a wide range of nuclear and membrane-bound receptors in the intestine and liver, thereby directly participating in the regulation of many molecular and biochemical processes [38].

Thus, FXR receptor in the liver activated by binding to BA inhibits 7-alpha-hydroxylase, an enzyme that catalyzes the main stages of the conversion of cholesterol to BA. A marked decrease in the activity of this enzyme reduced the levels of primary BA, and increased the intensity of lipogenesis and gluconeogenesis [39, 40]. This effect can be explained by another cascade reaction: the activation of FXR inhibits the sterol regulatory element-binding protein 1 (SREBP-1C), which is responsible for the synthesis of cholesterol and BA, and the capture and catabolism of fatty acids [41]. Taken together, the liver eventually develops dyslipidemia, insulin resistance, and steatosis.

According to previous scientific data, quantitative and qualitative changes in the intestinal microbiota of patients with liver diseases induce a secondary increase in the level of toxic unconjugated BA in the intestinal lumen, which damages the intestinal epithelium, increasing the permeability of the protective barrier [42]. As a result, a large amount of intestinal lipopolysaccharide enters the liver through the portal bloodstream, which triggers a cascade of pathological reactions including the hyperproduction of inflammatory mediators [43]. Indeed, the excessive production of TNF- $\alpha$ interacted with its corresponding membrane receptors on hepatocytes and inhibited the response to insulin, which also inhibited the activity of FXR [44]. According to the feedback principle, this activates the formation of BA with a predominance of cholic acid, an agonist of FXR and the BA membrane receptor TGR5 (a G-protein-coupled receptor). A secondary decrease in the activity of FXR and TGR5 contributed to an increase in the synthesis of fatty acids in the liver and a decrease in their catabolism, which led to the development of steatosis and the progression of non-alcoholic fatty liver disease [45].

TGR5 (also known as GP-Bar1) is widely expressed on the surface of the epithelium of the small intestine, Kupffer cells, endotheliocytes of the liver sinusoids, and the epithelium of the bile tubules. When this transmembrane receptor was activated, the response to insulin in the tissues and the production of glucagon-like peptide-1, GLP-1, were increased, which stimulated the formation and secretion of insulin by pancreatic cells [46]. It was assumed that the activation of TGR5 inhibited the inflammatory response of macrophages to lipopolysaccharide and reduced the migration of these cells to the hepatic parenchyma, but we still do not have a complete understanding of these processes [47].

In the context of this review, the results of a study by Ma et al. are particularly interesting and informative [48]. They showed that a modification of the intestinal microflora in a mouse model of liver cancer to increase the proportion of commensal bacteria contributed to an increase in a hepatic-selective antitumor effect, which was confirmed by a significant increase in the number of NKT cells in the hepatic parenchyma. NKT cells accumulated in the liver had high phenotypic activity when stimulated by antigen and produced more interferon- $\gamma$ compared with other immunocompetent clones. Further study demonstrated the survival and accumulation of NKT cells in the liver was regulated by the expression of chemokine type 6 receptor (CXCR6) on sinusoidal liver cells. Of note, the only ligand of the CXCR6 receptor is the protein chemokine CXCL16 [49], which was increased in association with an increase in the primary BA concentration. The authors of that study demonstrated that antibiotic therapy with vancomycin contributed to the elimination of Gram-positive bacteria from experimental mice, which mediated the metabolism of primary BA to secondary BA, which led to an increase in the number of NKT cells and a decrease in tumor growth in the liver. The introduction of secondary BA to mice with modified intestinal microbiota inhibited the accumulation of NKT cells in the hepatic parenchyma and increased the growth rate of the malignant liver tumor. Thus, this study allowed us to establish the following significant associations: the levels of primary BA (chenodeoxycholic acid) directly correlated with the expression of CXCL16, whereas there was an inverse correlation with secondary BA.

The substrates for gut microbiota markedly influence the content of short-chain fatty acids. Intestinal bacteria synthesize three main short-chain fatty acids: acetic (acetate), propionic (propionate), and butyric (butyrate) $[34,37]$. The most important short-chain fatty acid for the normal function of hepatocytes is propionate, which is transported to the liver where it is involved in gluconeogenesis and the synthesis of biogenic amines (hypolipidemic, hypoammonemic effect), improves microcirculation in the intestinal mucosa, and blocks the attachment of conditionally pathogenic microflora to colonocytes. Thus, a decrease in the proportion of specific short-chain fatty acids can aggravate inflammatory and 
dysmetabolic processes in the hepatic parenchyma, as well as accelerate the risk of undesirable side effects in liver diseases (in particular, hepatic encephalopathy) [40, 43]

Because of the lack of effective screening programs for high-risk groups and late diagnoses, the steady increase in the number of liver diseases continues to be an urgent and socially significant problem. In addition, the current treatment methods are often ineffective because of our poor understanding of the molecular and biochemical mechanisms related to the occurrence and development of liver pathology. Recent studies have reported a close interaction between the liver and intestine, termed the «intestinal-hepatic axis», but the interactions between its biochemical and molecular pathways are extremely complex and poorly understood. Nevertheless, many researchers agree that disorders of the intestinal microbiota contribute to chronic inflammation, the progression of changes in the hepatic parenchyma and its replacement with fibrous tissue or fat accumulation, and the direct inhibition of antitumor immune responses. Further research should significantly expand our understanding of the pathogenetic role of intestinal microflora and its metabolites in the occurrence and development of various liver diseases, as well as helping develop novel targeted therapies for liver disease.

Funding. The research was partially supported by the Development Program of the V. I. Vernadsky Crimean Federal University 2015-2024. (intramural grant for 20192020).

Disclosures: The authors declare no conflict of interest.

Acknowledgment. We thank J. Ludovic Croxford, PhD, from Edanz (www.edanz.com/ac) for editing a draft of this manuscript.

\section{References}

1. Turnbaugh P. J., Ley R. E., Hamady M., Fraserliggett C. M., Knight R. [et al.] The human microbiome project. Nature. 2007;449(7164):804-10 https://doi.org/10.1038/nature06244

2. O'Hara A. M., Shanahan F. The gut flora as a forgotten organ. EMBO. 2006;7:688-693. https://doi.org/10.1038/sj.embor.7400731

3. Marchesi J. R., Ravel J. The vocabulary of microbiome research: a proposal. Microbiome. 2015;3:31-35. https://doi.org/10.1186/s40168-015-0094-5

4. Zoetendal E. G., Rajilic-Stojanovic M., de Vos W. M. High through put diversity and functionality analysis of the gastrointestinal tract microbiota. Gut. 2008;57:1605-1615. https://doi.org/10.1136/gut.2007.133603

5. Arora T., Bäckhed F. The gut microbiota and metabolic disease: current understanding and future perspectives. Journal of Internal Medicine. 2016;280(4):339-349. https://doi.org/10.1111/joim.12508

6. Cresci G. A., Bawden E. Gut Microbiome: What We Do and Don't Know. Nutrition in Clinical Practice. 2015;30(6):73446. https://doi.org/10.1177/0884533615609899

7. Poluektova E. A., Ljashenko O. S., Shifrin O. S., Sheptulin A. A., Ivashkin V. T. Modern methods for studying the microflora of the human gastrointestinal tract. Rossijskij zhurnal gastrojenterologii, gepatologii, koloproktologii. Russian journal of Gastroenterology, Hepatology, Coloproctology. 2014:24(2):85-91.

8. Landman C., Qmvrain E. Gut microbiota: Description, role and pathophysiologic implications. La Revue de Médecine Interne. 2016;37(6):418-423.

https://doi.org/10.1016/j.revmed.2015.12.012

9. Shi N., Li N., Duan X., Niu H. Interaction between the gut microbiome and mucosal immune system. Military Medical Research. 2017:4:14.

https://doi.org/10.1186/s40779-017-0122-9

10. Guarner F., Malagelada J. R. Gut flora in health and disease. Lancet. 2003;361(9356):512-519. https://doi.org/10.1016/S0140-6736(03)12489-0

11. Boulangè C. L., Neves A. L., Chilloux J. Impact of the gut microbiota on inflammation, obesity, and metabolic disease. Genome Medicine. 2016;68:42-63. https://doi.org/10.1186/s13073-016-0303-2

12. Maynard C., Weinkove D. The Gut Microbiota and Ageing. Sub-cellular biochemistry. 2018;90:351-371. https://doi.org/10.1007/978-981-13-2835-0 12

13. Milosevic I., Vujovic A., Barac A., Djelic M.., Korac M. [et al.] Gut-Liver Axis, Gut Microbiota, and Its Modulation in the Management of Liver Diseases: A Review of the Literature. International journal of molecular sciences. 2019;20(2):395. https://doi.org/10.3390/ijms20020395

14. Federico A., Dallio M., Caprio G. G., Ormando V. M., Loguercio C. Gut microbiota and the liver. Minerva Gastroenterologica e Dietologica. 2017;63(4):385-398. https://doi.org/10.23736/S1121-421X.17.02375-3
15. Seki E., Schnabl B. Role of innate immunity and the microbiota in liver fibrosis: crosstalk between the liver and gut. The Journal of Physiology. 2012;590(3):447-458. https://doi.org/10.1113/jphysiol.2011.219691

16. Seo Y. S., Shab V. H. The role of gut-liver axis in the pathogenesis of liver cirrhosis and portal hypertension. Clinical and Molecular Hepatology. 2012;18(4):337-346.

https://doi.org/10.3350/cmh.2012.18.4.337

17. Boursier J., Mueller O., Barret M., Machado M., Fizanne L. [et al.] The severity of nonalcoholic fatty liver disease is associated with gut dysbiosis and shift in the metabolic function of the gut microbiota. Hepatology. 2016;63(3):764-75. https://doi.org/10.1002/hep.28356

18. Bajaj J S Heuman D. M , Hylemon P B Fisher A R. Sikaroodi M. [et al.] Altered profile of human gut microbiome is associated with cirrhosis and its complications. Journal of Hepatology. 2014;60:940-7. https://doi.org/10.1016/j.jhep.2013.12.019

19. Delzenne N. M., Knudsen C., Beaumont M., Rodriguez J., Neyrinck A. M. [et al.] Contribution of the gut microbiota to the regulation of host metabolism and energy balance: a focus on the gut-liver axis. The Proceedings of the Nutrition Society. 2019;78(3):319-328. https://doi.org/10.1017/S0029665118002756

20. Michail S. Lin M. Frey M. R., Fanter R . Paliy O. [et al.] Altered gut microbial energy and metabolism in children with non-alcoholic fatty liver disease. FEMS Microbiology Ecology. 2015;91(2):1-9. https://doi.org/10.1093/femsec/fiu002

21. Raman M., Ahmed I., Gillevet P. M. Fecal microbiome and volatile organic compound metabolome in obese humans with nonalcoholic fatty liver disease. Clinical Gastroenterology and Hepatology. 2013;11(7):868-75. https://doi.org/10.1016/j.cgh.2013.02.015

22. Grat M., Wronka K. M., Krasnodębski M. Profile of Gut Microbiota Associated With the Presence of Hepatocellular Cancer in Patients With Liver Cirrhosis. Transplantation Proceedings. 2016;48:1687-1691. https://doi.org/10.1016/j.transproceed.2016.01.077

23. Xie G., Wang X., Zhao A. Sex-dependent effects on gut microbiota regulate hepatic carcinogenic outcomes. Scientific Reports. 2017;7:45232. https://doi.org/10.1038/srep45232

24. Schoeler M., Caesar R. Dietary lipids, gut microbiota and lipid metabolism. Reviews in Endocrine \& Metabolic Disorders. 2019;20(4):461-472.

https://doi.org/10.1007/s11154-019-09512-0

25. Paul B., Barnes S., Demark-Wahnefried W. Influences of diet and the gut microbiome on epigenetic modulation in cancer and other diseases. Clinical Epigenetics. 2015;7:112-129.

https://doi.org/10.1186/s13148-015-0144-7

26. Thaiss C. A., Zmora N., Levy M., Elinav E. The microbiome and innate immunity. Nature. 2016;535(7610):65-74. https://doi.org/10.1038/nature18847

27. Carbajo-Pescador S., Porras D., García-Mediavilla M. V. Martínez-Flórez S., Juarez-Fernández M. [et al.] Beneficial 
effects of exercise on gut microbiota functionality and barrier integrity, and gut-liver crosstalk in an in vivo model of early obesity and non-alcoholic fatty liver disease. Disease models \& mechanisms. 2019;12(5):dmm039206. https://doi.org/10.1242/dmm.039206

28. Xu R., Aruhan, Xiu L., Sheng S., Liang Y., Zhang H. [et al.] Exopolysaccharides from Lactobacillus buchneri TCP016 Attenuate LPS- and d-GalN-Induced Liver Injury by Modulating the Gut Microbiota. Journal of agricultural and food chemistry. 2019;67(42):11627-11637. https://doi.org/10.1021/acs.jafc.9b0432

29. Li R., Zhou R., Wang H., Li W., Pan M. [et al.] Gut microbiota-stimulated cathepsin $\mathrm{K}$ secretion mediates TLR4-dependent M2 macrophage polarization and promotes tumor metastasis in colorectal cancer. Cell Death \& Differentiation. 2019;26(11):2447-2463

https://doi.org/10.1038/s41418-019-0312-y

30. Liu D., Zhang Y., Liu Y., Hou L., Li S. [et al.] Berberine Modulates Gut Microbiota and Reduces Insulin Resistance via the TLR4 Signaling Pathway. Experimental and Clinical Endocrinology \& Diabetes. 2018;126(8):513-520. https://doi.org/10.1055/s-0043-125066

31. Law K., Brunt E. M. Nonalcoholic fatty liver disease. Clinics in Liver Disease. 2010;14(4):591-604. https://doi.org/10.1016/j.cld.2010.07.006

32. Park E. J., Lee J. H., Yu G. Y. Dietary and genetic obesity promote liver inflammation and tumorigenesis by enhancing IL-6 and TNF expression. Cell. 2010;140:197-208. https://doi.org/10.1016/j.cell.2009.12.052

33. Szabo G., Lippai D. Molecular hepatic carcinogenesis: impact of inflammation. Digestive Diseases. 2012;30(3):2438. https://doi.org/10.1159/000336913

34. Shiffka S. J., Kane M. A., Swaan P. W. Planar bile acids in health and disease. Biochimica et Biophysica Acta. Biomembranes. 2017;1859(11):2269-2276. https://doi.org/10.1016/j.bbamem.2017.08.019

35. Dawson P. A., Karpen S. J. Intestinal transport and metabolism of bile acids. Journal of Lipid Research. 2015;56(6):1085-99. https://doi.org/10.1194/jlr.R054114

36. Ridlon J. M., Harris S. C., Bhowmik S., Kang D. J., Hylemon P. B. Consequences of bile salt biotransformations by intestinal bacteria. Gut Microbes. 2016;7(1):22-39. https://doi.org/10.1080/19490976.2015.1127483

37. McGlone E. R., Bloom S. R. Bile acids and the metabolic syndrome. Annals of clinical biochemistry. 2019;56(3):326337. https://doi.org/10.1177/0004563218817798

38. Jung D., Podvinec M., Meyer U. A., Mangelsdorf D. J., Fried M. [et al.] Human organic anion transporting polypeptide 8 promoter is transactivated by the farnesoid $X$ receptor/bile acid receptor. Gastroenterology. 2002;122(7):195466. https://doi.org/10.1053/gast.2002.33583
39. Norlin M., Andersson U., Björkhem I., Wikvall K. Oxysterol 7 alpha-hydroxylase activity by cholesterol 7 alpha-hydroxylase (CYP7A). The Journal of biological chemistry. 2000;275(44):34046-53. https://doi.org/10.1074/jbc.M002663200

40. Russell D. W. The enzymes, regulation, and genetics of bile acid synthesis. Annual Review of Biochemistry. 2003;72(1):137-74. https://doi.org/10.1146/annurev.biochem.72.121801.161712

41. Bai X., Dong F., Yang G. Influences of sterol regulatory element binding protein-1c silencing on glucose production in HepG2 cells treated with free fatty acid. Lipids in Health and Disease. 2019;18:89.

https://doi.org/10.1186/s12944-019-1026-3

42. Ji Y., Yin Y., Li Z., Zhang W. Gut Microbiota-Derived Components and Metabolites in the Progression of Non-Alcoholic Fatty Liver Disease. Nutrients. 2019;11(8):1712. https://doi.org/10.3390/nu11081712

43. Suk K. T., Kim D. J. Gut microbiota: novel therapeutic target for nonalcoholic fatty liver disease. Expert Review of Gastroenterology \& Hepatology. 2019;13(3):193-204. https://doi.org/10.1080/17474124.2019.1569513

44. Keitel V., Görg B., Bidmon H. J., Zemtsova I., Spomer L. [et al.] The bile acid receptor TGR5 (Gpbar-1) acts as a neurosteroid receptor in brain. Glia. 2010;58(15):1794805. https://doi.org/10.1002/glia.21049

45. Keitel V., Häussinger D. Role of TGR5 (GPBAR1) in Liver Disease. Seminars in Liver Disease. 2018;38(4):333-339. https://doi.org/10.1055/s-0038-1669940

46. Alemi F., Poole D. P., Chiu J., Schoonjans K., Cattaruzza F. [et al.] The receptor TGR5 mediates the prokinetic actions of intestinal bile acids and is required for normal defecation in mice. Gastroenterology. 2013;144(1):145-54. https://doi.org/10.1053/j.gastro.2012.09.055

47. Deutschmann K., Reich M., Klindt C., Dröge C., Spomer L. [et al.] Bile acid receptors in the biliary tree: TGR5 in physiology and disease. Biochimica et Biophysica Acta. Molecular Basis of Disease. 2018;1864:1319-1325. https://doi.org/10.1016/j.bbadis.2017.08.021

48. Ma C., Han M., Heinrich B., Fu Q., Zhang Q. [et al.] Gut microbiome - mediated bile acid metabolism regulates liver cancer via NKT cells. Science. 2018;360(6391):5931. https://doi.org/10.1126/science.aan5931

49. Geissmann F., Cameron T. O., Sidobre S., Manlongat N., Kronenberg M. [et al.] Intravascular immune surveillance by $\mathrm{CXCR6}^{+}$NKT cells patrolling liver sinusoids. PLOS Biology. 2005;3(4):113. https://doi.org/10.1371/journal.pbio.0030113

\section{About autors:}

Shevandova Alina Alekseevna, student;

e-mail: Shevandova_A_A@mail.ru; https://orcid.org/0000-0002-9448-6034

Fomochkina Iryna Ivanovna, MD, DMSc, Professor of the Department of general and clinical pathophysiology;

tel.: +73652554940; e-mail: fomochkina_i@mail.ru; https://orcid.org/0000-0003-3065-5748

Kubyshkin Anatoliy Vladimirovich, MD, DMSc, Professor,

Head of the Department of general and clinical pathophysiology;

tel.: +73652554940; e-mail: kubyshkin_av@mail.ru; https://orcid.org/0000-0002-1309-4005

Sorokina Leya Evgenyevna, student;

тел.: +79782094673; e-mail: leya.sorokina@mail.ru; https://orcid.org/0000-0002-1862-6816

Gordienko Andrey Ivanovich, Leading Researcher at the Central Research Laboratory;

tel.: +79787819622; e-mail: uu4jey@mail.ru

Gorbunov Aleksandr Andreevich, student;

tel.: +79785240508; e-mail: sashaagor@mail.ru; https://orcid.org/0000-0002-2886-6178

Makalish Tatyana Pavlovna, CBiolSc, Junior Researcher at the Central Research Laboratory;

tel.: 89787853919; e-mail: gemini_m@list.ru; https://orcid.org/0000-0003-1884-2620

Yurchenko Ksenia Andreevna, postgraduate student,

tel.: +79788958417; e-mail: yurchenkokseniya28@gmail.ru; https://orcid.org/0000-0002-0284-7059 